\title{
SIMPTOMS OF ANXIETY, DEPRESSION, ANGER AND SEXUAL CONCERN AND THE ROLE OF SOME DEMOGRAPHIC CHARACTERISTIC AMONG SLOVENIAN YOUTH: A CROSS SECTIONAL STUDY \\ ZNAKI DEPRESIVNOSTI, ANKSIOZNOSTI, JEZAVOSTI IN SPOLNIH PREOKUPACIJ TER VLOGA NEKATERIH DEMOGRAFSKIH KARAKTERISTIK MED MLADIMI V SLOVENIJI: PRESEČNA ŠTUDIJA Maša Černelič Bizjak ${ }^{1}$
}

Prispelo: 30. 3. 2011 - Sprejeto: 26. 8. 2011

Original scientific article UDC 613.88-053.6(497.4):316.346

\begin{abstract}
Background: There is some evidence that a more elevated level of anxiety and depression is associated with adolescent timing and that depression and anxiety have overlapping symptoms and are conceptually interrelated. Methods: This cross-sectional study investigated the clinical importance and comorbidity rates of some psychological symptoms. The aim was to explore the presence and intensity of the symptoms of anxiety, depression, anger and sexual concern in Slovenian adolescents. The second aim was to determine the relationship between the sociodemographic characteristics of adolescents and the presence of these symptoms. Two hundred and three adolescents between 15 and 20 years of age completed a questionnaire measuring specific symptoms.

Results and conclusions: The results of the current study indicate that depressive and anxiety symptoms were found not to differ by gender, age and socioeconomic status. Girls and boys showed similar profiles of correlations for depressive and anxiety symptoms. High level of depressive symptoms, such a feelings of sadness, unhappiness, and loneliness, were associated with increased symptoms of anxiety among boys and girls and both expressed more sexual concerns as well. Anger, angry thoughts, feelings and behaviour were strongly linked to preoccupation with sexual thoughts or feelings for both boys and girls. The findings extend the current knowledge in this area. Identifying and assessing depression and other symptoms are essential to ensuring access to appropriate treatment.
\end{abstract}

Key words: adolescents, health, depression, anxiety, anger, gender, age, psychology

Izvirni znanstveni članek

Izvleček

UDK 613.88-053.6(497.4):316.346

Namen: Nekateri dokazi kažejo, da se povečana stopnja anksioznosti in depresivnosti povezuje z obdobjem adolescence ter da znaki sovpadajo in se povezujejo med seboj.

Metode: Ta presečna študija raziskuje klinično pomembnost in stopnjo komorbidnosti nekaterih psiholoških znakov, to je: depresije, anksioznosti, jeze in skrbi glede spolnosti in povezave med temi znaki med slovensko mladino. Cilj študije je bil določiti tudi vlogo specifičnih demografskih značilnosti, ki so mogoče povezane s povečano stopnjo psiholoških znakov. Dvesto trije adolescenti, stari od 15 do 20 let, so izpolnili klinično lestvico, ki meri specifične znake. Rezultati in zaključki: Rezultati študije kažejo, da pojavljanje depresivnih in anksioznih znakov ni odvisno od spola, starosti ali od socialno-ekonomskega statusa. Dekleta in fantje kažejo podoben profil povezav med depresivnimi in anksioznimi znaki. Visoka stopnja depresivnosti, kot so na primer občutki žalosti, nesreče in osamljenosti, so bili povezani s povečano stopnjo anksioznosti pri fantih in dekletih. Oboji izkazujejo tudi več skrbi glede spolnosti. Jeza, jezne misli, občutki jeze in vedenje so bili močno povezani s prevzetostjo z mislimi in občutki glede spolnosti pri fantih 
in dekletih. Rezultati širijo dozdajšnje znanje na tem področju. Identifikacija in ustrezno obravnavanje depresivnosti in drugih z njo povezanih znakov je nujno za zagotavljanje pristopov primerne obravnave ali zdravljenja.

Ključne besede: adolescenti, zdravje, depresija, anksioznost, jeza, spol, starost, psihologija

\section{INTRODUCTION}

Depression in children and adolescents has been a frequent focus of research in clinical and developmental psychology in the last 3 decades (see reviews 1-5). Much of this research has sought to document changes with age in the prevalence of depressive symptoms, particularly as children transition into adolescence $(1,4)$. Other works have focused on differences in the prevalence of depression associated with gender or socioeconomic status and association between anxious/depressed symptoms $(3,5)$.

Adolescence, more than any other developmental period, entails experimentation, exploration and risk taking and represent the path from childhood and the safe haven of the family into the world and towards independence. It is a time of storm and stress, intense moodiness and preoccupation with the self (4). $40 \%$ to $70 \%$ of adolescents also experience one or more stressful events before the age of $18(6,7)$. Like other phases of the life course, adolescence also includes the experience of stressful life events, with some likely to be more frequent or stressful at this age (8).

Adolescence is also an important developmental period for understanding the nature, course and treatment of depression, anxiety and other symptoms (4). Identifying and assessing depression and other symptoms are essential to ensuring access to appropriate treatment and services. In fact, depression is the most common mental health concern in this age group. The lifetime prevalence rates of unipolar depression (27.16\%) and major depression $(24.80 \%)$ in adolescent girls (a mean age of 16.6 years) were more than double that for anxiety disorders (11.67\%) (9). A number of high quality studies have also chronicled the prevalence and consequences of anxiety symptoms and disorders in adolescent samples (10-14). For example, the comorbidity of depression and anxiety disorders is estimated at $30 \%$ to $70 \%$. It has been estimated that $40 \%$ to $90 \%$ of depressed adolescents have at least one comorbid disorder (15), the most frequent being anxiety, oppositional defiant disorder and conduct disorder (e.g., 16). In the study by Rohde et al. (17), $21 \%$ of the sample was diagnosed as having an anxiety disorder, but depression stands out among the psychological problems in adolescence, both for its impact on adjustment during the adolescent years and its long-term effects on adult psychological functioning.
Depression and anxiety in adolescence may result in negative consequences in young adulthood (9). It has been related prospectively to poorer health in several investigations (18-21). For example, Bardone and colleagues conducted longitudinal study and concluded that adolescents with depression had more medical problems in early adulthood, even after controlling for socioeconomic status, parental smoking, childhood and maternal health, and maternal body mass index (18). Schraedley et al. (20) assessed healthcare utilization in a large nationally representative sample of adolescents and found that higher levels of depressive symptoms were associated with a greater frequency of general health visits. In fact, adolescents with the highest levels of depression symptoms were twice as likely to have seen a doctor five or more times in the previous year than those with the lowest levels of depression symptoms.

The gender difference in depression and anxiety symptoms is among the most robust of findings in psychopathology research. All the evidence suggests that increases in depressive disorders and mood are greater for girls than for boys during adolescence (e.g. 22-27). The gender difference that emerges by 14-15 years of age appears to persist into adulthood (4). Among girls, advancing pubertal status is generally associated with an increased likelihood of anxiety symptomatology, including panic attacks (23). The findings among boys are more mixed, although $\mathrm{Ge}$ and colleagues (28) provide some evidence of a similar trend as observed for girls. This indicates that girls are at greater risk of developing various mental disorders (29). Estimates are that, in adulthood, twice as many women as men are depressed (30-32). Research also indicates that, although girls are no more depressed than boys in childhood (33-35), more girls than boys are depressed by the ages 13 to $15(26,27,29,36)$ with significantly lower self-esteem (37). If we are to understand the gender difference in psychopathology in adulthood, we must understand its development and correlations in the period of adolescence.

The aims of the present study were threefold: a) to examine the clinical importance and comorbidity rates of some psychological symptoms, more precisely depression, anxiety, anger and sexual concerns in adolescence, $b$ ) to determine some characteristics of adolescents who scored high on depression and/or other clinical scales, c) to determine what demographic 
factor are associated with an elevated level of specific symptoms.

\section{METHODS}

\subsection{Participants}

We begin with a simple random sample of secondary schools in Slovenia. Within these schools, we did a simple random sample of classes and within the classes we did a simple random sample of students who agreed to participate in the study.

At the baseline, 240 adolescents from 12 public secondary schools in Slovenia were recruited on our study site. Some were excluded from the analysis due to incomplete questionnaires; therefore, the final sample consisted of 203 adolescents (114 girls and 89 boys). This is $85 \%$ of the primary research sample. Ages ranged from 15 to 20 at the time of assessment, the average age was $17.23 \pm 1.21$ years. $34 \%$ of adolescents were 18 years old, $21 \%$ were 19 years old, $16 \%$ were 21 years old, $11 \% 17$ years old, $9 \%$ 20 years and $6 \% 16$ years old.

We examined socioeconomic status (SES) by questioning adolescents about the education of their mothers (34\% of mothers finished primary school; $58 \%$ finished secondary school; $8 \%$ finished high school or more).

Participation in the research was voluntary and the questionnaires were completed anonymously.

\subsection{Measures}

All the participants were evaluated according to the results obtained by psychological assessment - The Trauma Symptom Checklist for Children (TSCC) (38). The Trauma Symptom Checklist for Children (TSCC) is a self-report psychological measurement of 'post-traumatic distress and related psychological symptomatology' in male and female children. We chose this psychological assessment because most research measures typically lack the reliability and validity of a test in clinical and non-clinical groups and they cannot be applied with confidence. In contrast to these research measures, there are only two standardized, normed tests available to clinicians; one is TSCC. The TSCC "was developed as a self-report scale for youths aged 7 to 16 years to assess distress and related symptoms and has a large normative base of ethnically and economically diverse children who do not have a history of trauma and can be used to interpret the child's level of symptomatology (39).
The TSCC is a 54-item self-report instrument (40). There are six clinical scales within the TSCC: Anxiety, Depression, Posttraumatic Stress, Sexual Concerns, Dissociation and Anger. Each symptom item is rated according to its frequency of occurrence using a fourpoint scale ranging from 0 ("never") to 3 ("almost all of the time"). The TSCC scales correlated most with scales of similar content (concurrent validity) and least with scales of less similar content (discriminant validity). Briere (40) found significant intercorrelations between the TSCC and Youth and Parent Report versions of the Child behaviour Checklist (CBCL) and the Children's Depression Inventory (CDI). The reliability analysis of the TSCC scales demonstrated high internal consistency (Cronbach's $\alpha$ alpha from 0.82 to 0.89) (40). Participants also completed additional questions about their age, sex and mother's education.

\subsection{Procedure}

The instructions were given carefully, such as explaining the study to the participants, affirming confidentiality and respecting either willingness or unwillingness to participate. The testing was conducted by a competent practising psychologist. To test for such a sensitive subject as suffering in groups of 3 to 7 adolescents, the participants were informed that the responses are rendered privately.

\subsection{Statistical Analysis}

Basic descriptive analyses were conducted first. T-test analyses were performed on the data to assess the influence of demographic variables. The distribution of the scores (TSCC) deviated from the normal distribution (Shapiro-Wilk's statistics were statistically significant for almost all the scores), so we performed a non-parametric test, the Mann-Whitney $U$ test (used for two independent samples)and the Kruskal-Wallis test $\mathrm{H}$ (for several independent samples). We analyse the relationship between four clinical scales and two subscales (the Pearson coefficient of correlation) between four clinical scales and two subscales. Statistical hypotheses were tested at $\alpha$ - level .05. All the statistical analysis was done with the SPSS 17.0 statistical package for Windows.

\section{RESULTS}

The descriptive statistics (means and standard deviations) of four clinical scales within the TSCC (anxiety, depression, anger and sexual concerns) 
and two subscales (sexual preoccupation and sexual distress) for girls and boys are presented in Table 1.

Table 1. The means and standard deviations for four clinical scales and two subscales of the Trauma Symptom Checklist for Children raw score conversions to $T$ scores for a sample of adolescents.

Tabela 1. Povprečne vrednosti in standardne deviacije za štiri klinične lestvice in dve podlestvici za Vprašalnik travmatiziranosti za otroke pretvorjene surove vrednosti $v$ T-vrednosti za skupino adolescentov.

\begin{tabular}{|c|c|c|c|c|c|}
\hline & & $n$ & $M$ & $S D$ & $\begin{array}{l}T \text { scores I } \\
T \text {-vrednosti }\end{array}$ \\
\hline \multirow{2}{*}{$\begin{array}{l}\text { ANXIETY (ANX) / } \\
\text { ANKSIOZNOST }\end{array}$} & Female / ženske & 114 & 6.73 & 4.26 & 51 \\
\hline & Male / moški & 89 & 6.36 & 3.34 & 56 \\
\hline \multirow{2}{*}{ DEPRESSION (DEP) / DEPRESIVNOST } & Female / ženske & 114 & 6.64 & 5.1 & 47 \\
\hline & Male / moški & 89 & 6.36 & 3.6 & 55 \\
\hline \multirow{2}{*}{ ANGER (ANG) / JEZAVOST } & Female / ženske & 114 & 4.64 & 3.25 & 51 \\
\hline & Male / moški & 89 & 5.79 & 4.04 & 51 \\
\hline \multirow{2}{*}{$\begin{array}{l}\text { SEXUAL CONCERNS (SC) / } \\
\text { SPOLNOST }\end{array}$} & Female / ženske & 114 & 6.00 & 4.18 & 48 \\
\hline & Male / moški & 89 & 10.71 & 5.19 & 54 \\
\hline \multirow{2}{*}{$\begin{array}{l}\text { SEXUAL PREOCCUPATION (SC-P) / } \\
\text { SPOLNA PREOKUPACIJA }\end{array}$} & Female / ženske & 114 & 4.29 & 3.50 & 46 \\
\hline & Male / moški & 89 & 8.93 & 4.61 & 53 \\
\hline \multirow{2}{*}{$\begin{array}{l}\text { SEXUAL DISTRESS (SC-D) } \\
\text { STISKA ZARADI SPOLNOSTI }\end{array}$} & Female / ženske & 114 & 2,05 & 1,98 & 49 \\
\hline & Male / moški & 89 & 2,71 & 2,55 & 56 \\
\hline
\end{tabular}

Two profile forms (male and female) that allow raw score conversions to $\mathrm{T}$ scores are provided in the TSCC materials. A graph of the profile may be drawn to visually portray the respondent's scores relative to the normative sample. For all the clinical scales (except SC and its subscales), the T scores at or above 65 are considered clinically significant. The $T$ scores in the range of 60 through 65 are suggestive of difficulty or may represent sub-clinical symptoms. For the SC scale and its subscales (SC-P and SC-D), T scores at or above 70 are considered clinically significant (40). Each of the critical items also requires attention in interpretation. None of the measured values in our sample of adolescents reached clinical importance on any of the clinical scales.

\subsection{The Impact of Demographics Variables}

Various analyses were performed on the data to assess the influence of demographic variables raw scores. First we tested gender differences. The independent samples $\mathrm{t}$ - test did not reveal a statistically significant gender difference on the three clinical scales (anxiety, depression, anger).

Within the group of adolescents, the results indicated differences between boys and girls on the clinical scale: sexual concerns-SC $(\mathrm{t}(201)=0.514, \mathrm{p}<.05)$ and sexual preoccupation - SC-P $(\mathrm{t}(201)=.707, \mathrm{p}<.01)$. Boys tended to have higher sexual concerns and sexual preoccupations.

We tested for differences between the subgroups of age (two groups: ranging in age from 15-18 and 19 to 20) and socioeconomic status (SES) (three groups). The Mann Whitney $U$ test did not reveal any statistically significant differences between the age subgroups on the four clinical scales (anxiety, depression, anger and sexual concerns) or on the two subscales of TSCC ( $p>$.05). TheKruskal-Wallis test $\mathrm{H}$ did not reveal a statistically significant difference between socioeconomic status subgroups on the four clinical scales (anxiety, depression, anger and sexual concerns) or on the two subscales of TSCC (df $=2$; $p>$.05). No statistically relevant relationships were found between age, sex and socioeconomic status and the tested TSCC clinical scales.

\subsection{Correlation between the clinical scales (TSCC)}

In Table 2, an intercorrelation between the clinical scales could be found for the group. We found a positive and moderate but significant ( $p>.01)$ correlation between all the clinical scales except SC-P. We also found a high positive correlation between $\mathrm{SC}$ and SC-P $(r=.901, p<.01)$. 
Table 2. The Pearson coefficients of the correlation between four clinical scales and two subscales.

Tabela 2. Pearsonovi korelacijski koeficienti med vsemi štirimi kliničnimi lestvicami in dvema podlestvicama.

\begin{tabular}{|c|c|c|c|c|c|c|}
\hline & ANX & DEP & ANG & SC & SC -P & SC-D \\
\hline \multicolumn{7}{|l|}{ ANX } \\
\hline \multicolumn{7}{|c|}{1} \\
\hline \multicolumn{7}{|l|}{ DEP } \\
\hline ,739** & 1 & & & & & \\
\hline \multicolumn{7}{|l|}{ ANG } \\
\hline, $550^{\star *}$ &, $544^{* *}$ & 1 & & & & \\
\hline \multicolumn{7}{|l|}{ SC } \\
\hline ,399* & ,402* & 260 & 1 & & & \\
\hline \multicolumn{7}{|l|}{ SC-P } \\
\hline ,713* & 390, & ,450* & ,901** & 1 & & \\
\hline \multicolumn{7}{|l|}{ SC-D } \\
\hline, $765^{* *}$ &, $692^{* *}$ &, $394^{*}$ & $643^{* *}$ & 276 & 1 & \\
\hline
\end{tabular}

** The correlation is significant at the 0.01 level (2-tailed).

* The correlation is significant at the 0.05 level (2-tailed).

\section{DISCUSSION}

The findings indicated that adolescents from our community sample did not show high level symptoms of depression, such as feelings of sadness, unhappiness, loneliness and episodes of tearfulness, or depressive cognitions such as guilt and self-denigration, selfharming and suicide (see Table 1 and 2). They also showed a low level of generalized anxiety, hyper arousal, worry, episodes of free-floating anxiety and a sense of impending anger and sexual concerns. The results of our study are inconsistent with some research regarding the prevalence of depression and anxiety among this age group (see 9, 41, 42). Possible explanations of our findings in this study could be cultural differences or good professional coverage in schools, where children and adolescents can be professionally educated. Consistent with others research (e.g. 15, 16, 17), we found that more anxious adolescents showed more feelings of depression, feelings of sadness, unhappiness and loneliness, expressing more sexual concerns as well. Adolescents with strong anger, angry thoughts, feelings and behaviour were found to be more preoccupied with sexual thoughts or feelings (see Table 3).

It is interesting that gender was not found to be an important variable upon which the adolescent experienced clinical symptoms. Within the group of adolescents, the results only indicated differences between boys and girls on the clinical scale sexual concerns-SC and sexual preoccupation -the boys tended to have higher sexual concerns and sexual preoccupations. It appears that most adolescent girls and boys do not differ substantially in the amount of sadness, unhappiness, fear and anxiety that they experience. In comparison with the boys, the girls had no scores indicative of a clinically significant level of depression. The result did not confirm the findings that adolescent females show a higher level of depression or anxiety as was confirmed by a lot of other previous researches (22-25). In terms of demographics, some authors $(43,44)$ argue that the preponderance of girls follows the general trend in that girls are more frequently diagnosed as depressed.

The results also indicate no gender differences in experiencing anger or angry thoughts and feelings. Adolescent boys were not found "to be more angry" than girls. This finding is supported by previous studies that report no gender difference in the experience of anger in adolescents $(45,46)$. In fact, angry behaviour is a more externalized symptom and in general, the literature concurs with the findings of Ostrov, Offer and Howard (47) that adolescent girls are more prone to inwardly directed symptoms and adolescent boys are prone to act out, with anger and aggression. The clinical scale of anger in the TSCC includes items that 
describe behaviour, including feeling mad, feeling mean and hating others and having difficulty de-escalating anger $(38,40)$. This is all externalized behaviour and the relationship with aggression is not surprising.

On the other hand, the results did not support the hypothesis that adolescents of different ages and different socioeconomic statuses experienced diverse level of symptoms. Indeed, some studies and qualitative reviews have suggested that the prevalence of depressive symptoms increases from childhood into adolescence but only among girls and not among boys (e.g. 41, 42, 3). But it is also true that very few individual studies have had sufficient numbers of children and adolescents from different social classes to compare their levels of depression (5). In fact a low SES was correlated with a greater prevalence of depression and anxiety (48) and Weissman et al. (32) found that participants with depression had significantly lower socioeconomic status. Our study did not confirm this assumption.

\section{CONCLUSION}

Although the results do not permit definitive conclusions concerning mental health risks among Slovenian adolescents from this community sample, they nevertheless provide an insight and offer a direction for further research. The results imply that adolescent females and males of different ages and different socioeconomic statuses might experience a similar intensity of symptoms such as depression, anxiety and anger. The level of expressed symptoms is not clinically or sub-clinically significant according to the normative Slovenian sample. The findings also provide a basis for the comparison of adolescents in various countries. The results of this study may have been limited by the relatively small size and the fact that the nature of the study (cross-sectional design) limits conclusions related to change over time.

\section{References}

1. Cicchetti $D$, Toth SL. The development of depression in children and adolescents. Am Psychol 1998; 53: 221-241.

2. Kovacs M, Devlin B. Internalizing disorders in childhood. J Child Psychol Psychiatry 1998; 39: 47-63.

3. Nolen-Hoeksema S, Girgus J. The emergence of gender differences in depression during adolescence. Psychol Bull 1994; 115: 424-443.

4. Petersen AC, Compas BE, Brooks-Gunn J, Stemmler M, Ey S, Grant KE. Depression in adolescence. Am Psychol 1993; 48: 155-168.

5. Stavrakaki C, Gaudet M. Epidemiology of affective and anxiety disorders in children and adolescents. Psychiatr Clin North Am 1989; 12: 791-802.
6. Elliott DM. Traumatic events: prevalence and delayed recall in the general population. J Consult Clin Psychol 1997; 65: 811-820.

7. Giaconia RM, Reinherz HZ, Silverman AB, Pakiz BA, Frost AK, Cohen E. Traumas and posttraumatic stress disorder in a community population of older adolescents. J Acad Child Adolesc Psychiatry 1995; 34: 1369-1380.

8. Camarena P, Sarigiani P, Petersen AC. Gender specific pathways to intimacy in early adolescence. $J$ Youth Adolesc 1990; 19: 19-32.

9. Franko DL, Striegel-Moore RH, Bean J, Tamer R, Kraemer HC, Dohm F, Crawford PB, Schreiber G, Daniels SR. Psychosocial and health consequences of adolescent depression in black and white young adult women. Health Psychol 2005; 24: 586-593.

10. Essau CA. Comorbidity of anxiety disorders in adolescents. Depress Anxiety 2003; 18: 1-6.

11. Wittchen HU, Fehm L. Epidemiology and natural course of social fears and social phobia. Acta Psychiatr Scand 2003; 108: 417-418.

12. Huerta R, Brizuela-Gamino OL. Interaction of pubertal status, mood, and self-esteem in adolescent girls. J Reprod Med 2002; 47: 217-225.

13. Leen-Feldner EW, Reardon LE, McKee LG, Feldner MT, Babson $\mathrm{KA}$, Zvolensky M J. The interactive role of anxiety sensitivity and pubertal status in predicting anxious responding to bodily sensations among adolescents. J Abn Child Psychol 2006; 34: 797-810.

14. McCabe MP, Ricciardelli LA, Banfield S. Body image, strategies to change muscles and weight, and puberty: do they impact on positive and negative affect among adolescent boys and girls? Eat Behav 2001; 2, 129-149.

15. Angold A, Costello EJ, Erkanli A. Comorbidity. J Child Psychol Psychiatry 1999; 40: 57-87.

16. Costello EJ, Mustillo S, Erkanli A, Keeler G, Angold A. Prevalence and development of psychiatric disorders in childhood and adolescence. Arc Gen Psychiatry 2003; 60: 837-844.

17. Rohde P, Lewinsohn PM, Seeley JR. Comorbidity of unipolar depression: comorbidity with other mental disorders in adolescents and adults. J Abnorm Psychol 1991; 100: 214-222.

18. Bardone AM, Moffitt TE, Caspi A, Dickson N, Stanton WR, Silva PA. Adult physical health outcomes of adolescent girls with conduct disorder, depression, and anxiety. J Am Acad Child Adolesc Psych 1998; 37: 594-601.

19. Newman MG, Clayton L, Zuellig A, Cashman L, Arnow B, Dea R. et al. The relationship of childhood sexual abuse and depression with somatic symptoms and medical utilization. Psychol Med 2000; 30: 1063-1077.

20. Schraedley PK, Gotlib IH, Hayward C. Gender differences in correlates of depressive symptoms in adolescents. J Adolesc Health 1999; 25: 98-108.

21. Shrier LA, Harris SK, Beardslee WR. Temporal associations between depressive symptoms and self-reported sexually transmitted disease among adolescents. Arch Pediatr Adolesc Med 2002; 156: 599-606.

22. Chartier GM, Lassen MK. Adolescent depression: Children's Depression Inventory norms, suicidal ideation, and (weak) gender effects. Adolescence 1994; 29: 859-864.

23. Blumenthal H, Leen-Feldner E, Trainor C, Babson K. Interactive roles of pubertal timing and peer relations in predicting social anxiety symptoms among youth. J Adol Health 2009; 44: 401-403.

24. Overholser JC, Adams DM, Lehnert KL, Brinkman DC. Selfesteem deficits and suicidal tendencies among adolescents. J Am Acad Child Adolesc Psych 1995; 34: 919-928. 
25. Zhang J, Jin S. Determinants of suicide ideation: a comparison of Chinese and American college students. Adolescence 1996; 31: 451-467.

26. Twenge J, Nolen-Hoeksema S. Age, gender, race, socioeconomic status, and birth cohort differences in the Children's Depression Inventory: a meta-analysis. J Abnorm Psychol 2002; 111: 578-588.

27. Wade R J, Cairney J, Pevalin D. Emergence of gender differences in depression during adolescence: national panel results from three countries. J Am Acad of Child Adolesc Psych 2002; 41: 190-198.

28. Ge X, Conger RD, Elder GH. The relation between puberty and psychological distress in adolescent boys. J Res Adolesc 2001; 11: 49-70.

29. Wasserman G, McReynolds L, Katz L, Carpenter J. Gender differences in psychiatric disorders at juvenile probation intake. Am J Public 2005; 95: 131-137.

30. Lucht M, Schaub RT, Meyer C, Hapke U, Rumpf HJ, Bartels T. et al. Gender differences in unipolar depression: a general population survey of adults between age 18 to 64 of German nationality. J Affec Disor 2003; 77: 203-211.

31. Piccinelli M, Wilkinson G. Gender differences in depression. $\mathrm{Br}$ J Psych 2000; 177: 486-492.

32. Weissman M, Bland R, Canino G, Faravelli C, Greenwald S, Hwu H. et al. Cross-national epidemiology of major depression and bipolar disorder. JAMA 1996; 276: 293-299.

33. Anderson J, Williams S, McGee R, Silva P. DSM-III disorders in adolescent children: prevalence in a large sample from the general population. Arch Gen Psychiatry 1987; 44: 69-76.

34. Cohen P, Cohen J, Kasen S, Velez C, Hartmark C, Johnson J. et al. An epidemiological study of disorders in late childhood and adolescence, I: Age- and gender-specific prevalence. J Child Psychol Psych 1993; 34: 851-867.

35. Rutter M. The developmental psychopathology of depression: issues and perspectives. In: Rutter M, Izard C, Read P, editors. Depression in young people. New York: Guilford Press, 1986.
36. Hankin BL, Mermelstein R, Roesch L. Sex differences in adolescent depression: stress exposure and reactivity models. Child Dev 2007; 78: 279-295.

37. Dolenc P. Telesna samopodoba in samospoštovanje osnovnošolskih otrok. Pedagoška obzorja 2008; 23: 53-61.

38. Briere J, Žemva B, Boben D. Trauma symptom check for children: Slovenian version. Ljubljana: Center za psihodiagnotična sredstva, 2000

39. Ohan JL, Myers K, Collett BR. Ten-year review of rating scales, IV: Scales assessing trauma and its effects. J Am Acad Child Psy 2002; 41: 1401-1422.

40. Briere J. Trauma symptom checklist for children: professional manual. Florida: Psychological Assessment Resources, 1996.

41. Hankin BL, Abramson LY. Development of gender differences in depression: an elaborated cognitive vulnerability-transactional stress theory. Psychol Bull 2001; 127: 773-796.

42. Hankin, BL, Abramson LY. Development of gender differences in depression: description and possible explanations. Ann Med 1999; 31: 372-379.

43. Glick I. Treating depression. San Francisco: Jossey Bass, 1995.

44. Hammen C. Mood disorders (unipolar depression). In: Herson M, Turner S, editors. Adult psychopathology and diagnosis. 2nd ed. New York: John Wiley \& Sons, 1999: 170-207.

45. Zahn-Wexler C. Social problem-solving in disruptive preschool children: reactions to hypothetical situations of conflict and distress. Merrill Palmer Q 1994; 40: 98-119.

46. Swaffer T, Epps K. The psychometric assessment of anger in male and female adolescents resident at a secure youth treatment centre. J Adolesc 1999; 22: 419-422.

47. Ostrov E, Offer D, Howard KI. Gender differences in adolescent symptomatology: a normative study. J Am Acad Child Adolesc Psych 1989; 28: 394-398.

48. Blazer DG, Kessler RC, McGonagle KA, Swartz MS. The prevalence and distribution of major depression in a national community sample: the national comorbidity survey. Am J Psych 1994; 151: 979-986. 